\title{
PERLINDUNGAN HUKUM TERHADAP INVESTOR ATAS TINDAKAN FORCED DELISTING PERUSAHAAN TERCATAT OLEH BURSA EFEK INDONESIA
}

\author{
Ahmad Wirayudha Nugraha \\ Universitas Indonesia \\ wirayudha773@gmail.com
}

\begin{abstract}
Abstrak
Perkembangan pasar modal saat ini sangat pesat, itu pun dipengaruhi oleh peranan yang strategis dalam pembangunan perekonomian di dunia, terkhusus untuk Indonesia. Selain sebagai pendanaan usaha, pasar modal juga berfungsi sebagai sarana bagi masyarakat untuk berinvestasi pada instrument keuangan. Perusahaan dalam mencari tambahan modal di pasar modal dapat melalui mekanisme listing di Bursa. Perusahaan yang terdaftar di Bursa tentunya harus mematuhi ketentuan yang berlaku seperti pengungkapan informasi, bertindak sesuai dengan aturan yang ditetapkan dan melindungi kepentingan investornya. Ketentuan tersebut jika diabaikan dapat mengakibatkan kurangnya performa dari perusahaan bahkan dapat dilakukan forced delisting dari Bursa. Hal ini akan merugikan pemegang saham yang memiliki saham di perusahaan yang terkena forced delisting. Perlindungan hukum terhadap investor atas diberlakukannya forced delisting telah diberikan dalam Undang-undang Nomor 8 tahun 1995 tentang Pasar Modal dan Undang-Undang Nomor 40 Tahun 2007 tentang Perseroan Terbatas mengenai kelalaian pengurus perusahaan yang menyebabkan perusahaan di forced delisting oleh Bursa Efek Indonesia. Sampai saat ini belum ada peraturan yang menegaskan bagi perusahaan yang di forced delisting untuk membeli kembali saham yang ada di masyarakat, akan tetapi ada OJK sudah berencana untuk mengaturnya lewat Rancangan Peraturan Otoritas Jasa Keuangan No. 04 Tahun 2020 Tentang Penyelenggaraan Kegiatan Di Bidang Pasar Modal yang akan diberlakukan kewajiban untu kemiten yang terkenaforced delistinguntukmembelikembalisaham yang sudahditerbitkannya (buyback).
\end{abstract}

\section{Kata Kunci : Pasar Modal, Penghapusan Pencatatan, Perusahaan Tercatat}

\begin{abstract}
The development of the capital market is currently very rapid, and even then influenced by a strategic role in economic development in the world, especially for Indonesia. Aside as a business funding, the capital market also has functions for the public to invest in financial instruments. can look for additional capital in the capital market through a listing mechanism on the Exchange. Companies that are listed on the stock exchange must comply with applicable regulations such as information disclosure, act in accordance with established rules and protect the interests of their investors. If ignored these provision can be result in a lack performance company and can even be forced delisting from the stock exchange. This will be detrimental to shareholders who have shares in the company affected by forced delisting. Legal protection of investors for enforcing forced delisting has been provided in Law Number 8 of 1995 concerning the Capital Market and Law Number 40 of 2007 concerning Limited Liability Companies regarding negligence of company management that causes public listed company to be forced delisted by the Indonesia Stock Exchange. Until now there has been no regulation that stipulates for public listed company that are forced to be delisted to buyback shares in the community, but there are OJK already planning to regulate them through the Financial
\end{abstract}


Services Authority Regulation Draft No. 04 of 2020 concerning the Implementation of Capital Market Activities which will impose an obligation for issuers affected by forced delisting to repurchase shares already issued (buyback).

\section{Keywords: Capital Market, delisting, Public Listed Companies}

\section{A. Pendahuluan}

Perkembangan pasar modal saat ini sangatpesat, itupundipengaruhi oleh peranan yang strategis dalam pembangunan perekonomian di dunia, terkhusus untuk Indonesia. ${ }^{1}$ Selain sebagai pendanaan usaha, pasar modal juga berfungsi sebagai sarana bagi masyarakat untuk berinvestasi pada instrumen keuangan. ${ }^{2}$ Saat ini disamping untuk menabung, melakukan investasi di pasar modal juga semakin berkembang di masyarakat. Banyak masyarakat kini menjadi investor dengan cara membeli saham perusahaan terbuka atau emiten yang terdaftar di Bursa Efek Indonesia (BEI). ${ }^{3}$ Bursa Efek Indonesia (BEI) mencatat jumlah investor pasar modal mengalami peningkatan 53\% di 2019. Jumlah investor pasar modal per 27 Desem-ber 2019 mencapai 2,47 juta investor. Se-dangkan pada 2018 hanya mencapai 1,62 juta investor. ${ }^{4}$

Secara sederhana, pasar modal dapat didefinisikan sebagai pasar yang memperjual belikan berbagai instrumen keuangan (sekuritas) jangka panjang, baik dalam bentuk utang maupun modal sendiri yang diterbitkan oleh perusahaan swasta. Tujuan pengembangan pasar modal akan

\footnotetext{
${ }^{1}$ Annisa Saumi, “OJK: Pasar modal Indonesia tumbuhpesatdari negara lain", https://www.alinea.id /bisnis/ojk-pasar-modal-indonesia-tumbuh-pesatdari-negara-lain-b1Xoz9o4h, diakses pada tanggal 20 Mei 2020

${ }^{2}$ Kansil, C.S.T., Pokok-Pokok Hukum Pasar Modal, (Jakarta: Pustaka Sinar Harapan, 2004) hlm 1

${ }^{3}$ Investor Daily, "MenjagaKepercayaan Pasar"https://investor.id/editorial/menjaga-

kepercayaan-pasar, diakses pada tanggal 1 april 2020

${ }^{4}$ Annisaayuartanti, BEI CatatJumlah Investor Pasar Modal Meningkat 53\%, https://www.medcom.id/ekonomi/bursa/ybJVw5ab2019-bei-catat-jumlah-investor-pasar-modalmeningkat-53 diakses pada tanggal 4 april 2020
}

semakin luas dan menyebar seiring dengan semakin berkembangnya aktivitas pasar modal Indonesia. Sudah menjadi keharusan dalam rangka memenuhi tuntutan kemajuan zaman serta menghadapi perkembangan ekonomi secara global dimasa yang akanda tang. Pasar Modal (bursa) adalah kegiatan yang bersangkutan dengan penawaran umum dan perdagangan efek, perusahaan publik yang berkaitan dengan efek yang diterbitkannya, serta lembaga dan profesi yang berkaitan dengan efek. ${ }^{5}$

Bagi perusahaan (emiten) yang memerlukan dana dari pasar modal harus melalui proses penawaran umum atau initial public offering (IPO) atau go public. Tanpa penawaran umum tersebut, efek tidak dapat diperdagangkan di bursal. Istilah penawaran umum adalah istilah hukum yang ditujukan bagi kegiatan suatu emiten untuk memasarkan, menawarkan, dan menjual efekefek yang diterbitkannya kepada masyarakat luas. ${ }^{6}$ Dengan demikian, penawaran umum itu untuk menjual efek misalnya saham atau obligasi yang dikeluarkannya kepada masyarakat. Dengan penjualan tersebut, emiten berharap mendapatkan dana yang dapat digunakan emiten untuk berbagai keperluan yang telah ditentukan sebelumnya.

Setelah emiten melakukan IPO, emiten dapat melakukan pencatatan (listing) atas saham yang dikeluarkannya di dalam bursa. Tujuan pencatatan ini agar sahamsahamnya mudah ditransaksikan oleh para pemodal yang telah membelinya atau pemodal yang ingin membeli saham-saham

\footnotetext{
${ }^{5}$ M.IrsanNasarudin, et al., AspekHukum Pasar Modal Indonesia, (Jakarta : KencanaPrenada Media Group, 2010), hlm. 13

${ }^{6}$ Ridwan Khairandy, Hukum Pasar Modal 1, (Ypgyakarta: FH UII Press, 2010) hlm. 115
} 
nya. ${ }^{7}$ Pencatatan (Listing) merupakan pencantuman suatu efek dalam daftar efek yang tercatat di bursa sehingga dapat diperdagangkan di bursa. ${ }^{8}$ Perusahaan tersebut wajib menyampaikan informasi penting yang berkaitan dengan tindakan atau Efek tersebut pada waktu yang tepat kepada masyarakat dalam bentuk laporan berkala dan laporan peristiwa penting. ${ }^{9}$

Namun, emiten yang melakukan listing memiliki konsekuensi untuk mengungkapkan informasi mengenai keadaan bisnisnya, termasuk keadaan keuangan, aspek hukum dari harta kekayaan, persoalan hukum yang dihadapi perusahaan dan manajemen. ${ }^{10}$ Factor keterbukaan (information disclosure) inilah yang sangat penting, meskipun secara finansial emitenini baik, bila tidak diiringi dengan keterbukaan informasi maka pemodal enggan menginvestasikan dananya keemiten tersebut. Faktor lainnya yaitu apabila emiten melanggar peraturanperaturan di dalam pasar modal. Apabila hal tersebut terjadi pada perusahaan go public (emiten) maka pencatatannya bisa dihapus oleh bursa, hal ini biasa disebut sebagai delisting.

Bursa memberikan ketentuan mengenai delisting dan relisting melalui Peraturan Nomor I-I tentang Penghapusan Pencatatan (delisting) dan Pencatatan Kembali (relisting) saham di bursa. Menurut Angka I.I4 Peraturan I-I tentang Penghapusan Pencatatan (delisting) dan Pencatatan Kembali (relisting) saham di bursa. Penghapusan Pencatatan (delisting) adalah penghapusan efek yang tercatat di Bursa sehingga Efek tersebut tidak dapat diperdagangkan di

${ }^{7}$ Hamud M. Balfas, Hukum Pasar Modal Indonesia, Jakarta: PT. Tata Nusa, 2012, hlm. 290.

${ }^{8}$ Bursa Efek Indonesia, Perubahan Peraturan Nomor I-A tentang Pencatatan Saham dan Efek Bersifat Ekuitas Selain Saham yang Diterbitkan Oleh Perusahaan Tercatat, Keputusan Direksi PT. Bursa Efek Indonesia No. Kep-OOI83/BE11122018, Pasal 1.15

${ }^{9}$ RepublikIndonesia, Undang-UndangTentang Pasar Modal No.8 Tahun 1995, Pasal 86 ayat 1.

${ }^{10}$ M. IrsanNasarudin, et. al., op. cit., hlm.
Bursa. $^{11}$ Penghapusan pencatatan saham perusahaan tercatat dari daftar efek yang tercatat di bursa dapat terjadi karena: ${ }^{12}$

a. Permohonan penghapusan pencatatan saham yang diajukan oleh perusahaan tercatat sendiri, yang biasanya disebut voluntary delisting;

b. Dihapus pencatatannya oleh bursa sesuai dengan ketentuan bursa karena tidak lagi memenuhi persyaratan yang ditentukan oleh bursa, yang biasanya disebut forced delisting.

Secara umum penghapusan paksa (forced delisting) hamper sama hasilnya dengan proses go private yaitu membuat perusahaan yang pada awalnya merupakan perusahaan yang sifatnya terbuka menjadi tertutup dan tidak lagi dapat diperdagangkan di bursa saham. Dalam Black's Law Dictionary go private adalah sebuah proses berakhirnya status perusahaan terbuka dikarenakan diakusisi oleh pemegang saham tunggal atau sebuah kelompok kecil. ${ }^{13}$

Sejauh ini, sudah banyak emiten yang didelisting oleh bursaseperti yang terjadi pada awaltahun 2020 iniseperti PT. Borneo Lumbung Energi\& MetalTbk (BORN) yang di delisting pada 20 Januari $2020^{14}$ dan PT. Leo Investment Tbk (ITTG) yang didelisting pada 23 Januari $2020^{15}$. Dengan dicabutnya status perseroan sebagai perusahaan tercatat (delisting) maka per-

11 Bursa Efek Indonesia, Peraturan No. I-I Tentang Penghapusan Pencatatan (delisting) dan Pencatatan Kembali (relisting) saham di bursa, Keputusan Direksi PT Bursa Efek Jakarta No. Kep308/BEJ/07-2004, Pasal I.14.

${ }^{12}$ Ibid., Pasal III.1.

${ }^{13}$ Black's Law Dictionary, hlm. 69.

${ }^{14}$ Wahyu Tri Rahmawati, Saham Borneo Lumbung Energi \& Metal (BORN) delisting hari ini, https://investasi.kontan.co.id/news/saham-borneolumbung-energi-metal-born-delisting-hari-ini, diakses pada tanggal 22 Mei 2020

$\begin{array}{llllr}{ }^{15} \text { Wahyu } & \text { Tri Rahmawati, BEI akan } & \text { delisting } & \text { saham Leo } \\ \text { Investments } & \text { (ITTG) } & \text { Kamis } & (23 / 1) & \text { besok, }\end{array}$ https://investasi.kontan.co.id/news/bei-akan-delisting-saham-leoinvestments-ittg-kamis-231-

besok\#: :text=BEI\%20delisting\%20paksa\%20Leo\%20Investments,lebih\% 20dari $\% 20$ dua $\% 20$ tahun $\% 20$ disuspensi.\&text=BEI $\% 20$ mengumumkan $\% 2$ 0potensi\%20delisting\%20ITTG,saham\%20emiten\%20pada\%2019\%20Des ember., diakses pada tanggal 22 Mei 2020 
seroan tidak lagi memiliki kewajiban sebagai perusahaan tercatat. Setelah status baru yang telah diputuskan oleh Bursa Efek Indonesia tersebut timbul permasalahan baru dimana apabila suatu perusahaan didelisting oleh Bursa maka otomatis investtor tidak dapat bisa bertransaksi lagi yang dikarena kan perusahaan tersebut mengakibatkan berubahnya status menjadi perusahaan privat atau tertutup. Tentunya hal ini akan merugikan bagi investor yang memegang saham perusahaan yang sudah di delisting tersebut. Jika dilihat dari sudut pandang investor, dimana para pemegang saham mayoritas tidak berkewajiban untuk membeli saham yang sudah beredar di masyarakat. Kewajiban perusahaan untuk melakukan pembelian kembali saham yang dimiliki oleh investor hanya berlaku dalam hal permohonan penghapusan pencatatan secara sukarela (voluntary delisting). Sementara itu, kewajiban perusahaan tercatat untuk membeli kembali (buyback) saham investor tidak terdapat dalam pengaturan forced delisting. ${ }^{16}$ Dengan demikian cukup menarik untuk mengetahui dan menganalisis lebih lanjut bagaimana perlindungan bagi para investor serta pertimbangan para pemegang otoritas dalam memutuskan delisting saham.

\section{B. Rumusan Masalah}

Berdasarkan pada latarbelakangtersebut, maka penulis tertarik untuk menguraikan lebih lanjut mengenai permasalahan sebagai berikut:

1. Apa pertimbangan Bursa Efek Indonesia dalam melakukan forced delisting kepada emitennya?

2. Bagaimana perlindungan hukum bagi investor yang mempunyai saham di emiten yang mengalami forced delisting?

\section{Pembahasan}

${ }^{16}$ Bursa Efek Indonesia, Peraturan No. I-I Tentang Penghapusan Pencatatan (delisting) dan Pencatatan Kembali (relisting) saham di bursa, Keputusan Direksi PT Bursa Efek Jakarta No. Kep308/BEJ/07-2004, Pasal III.2.1
1. Pertimbangan Bursa Efek Indonesia dalam melakukan forced delisting kepada emitennya

Kewenangan OJK dalam memberikan sanksi terhadap perusahaan yang bermasalah dapat dilihat dalam ketentuan UU Pasar Modal. Berdasar kanpasal 5 huruf J Undang-Undang Pasar Modal menyatakan bahwa OJK dapat melakukan pembatalan pencatatan efek atau menghentikan transaksi efek untuk jangka waktu tertentu. Tindakan penghapusan pencatatan dan penghentian transaksi sementara ini dilakukan dalam rangka memberikan perlindungan bagi investor. ${ }^{17}$ Pada prakteknya sanksi delisting merupakan pilihan terakhir yang dapat dijatuhkan oleh bursa.

Pada dasarnya delisting atas suatu saham dari daftar efek yang tercatat di Bursa dapat terjadi karena permohonan delisting saham yang diajukan oleh perusahaan tercatat yang bersangkutan (voluntary delisting) atau dihapus pencatatan sahamnya oleh Bursa (forced delisting). Delisting yang dilakukan oleh Bursa tidak dilakukan secaratiba-tiba, diawali dengan suspense atau penghentian sementara terhadap perdagangan saham perusahaan yang bersangkutan. Bursa Efek Indonesia mempunyai pertimbangan untuk melakukan forced delisting didasarkan pada Keputusan Direksi PT Bursa Efek Jakarta Nomor KEP-308/BEJ/07-2004 tentang Peraturan I-I Tentang Penghapusan Pencatatan (Delisting) dan Pencatatan Kembali (Relisting) Saham di Bursa.

Pada pasal III.3 dijelaskan beberapa hal yang menyebabkan forced delistingyaitu:

a. Mengalami kondisi, atau peristiwa, yang secara signifikan berpengaruh negatif terhadap kelangsungan usaha Perusahaan Tercatat, baik secara financial atau secara hukum, atau terhadap kelangsungan status Perusahaan Tercatat sebagai Perusahaan Terbuka, dan Perusahaan Tercatat tidak dapat

17 Indonesia, Undang-UndangTentang Pasar Modal, UU No. 8 Tahun 1995, Pasal 5 huruf J 
menunjukkan indikasi pemulihan yang memadai.

b. Saham Perusahaan Tercatat yang akibat suspense di Pasar Reguler dan Pasar Tunai, hanya diperdagangkan di Pasar Negosiasi sekurang-kurangnya selama 24 (dua puluh empat) bulan terakhir.

Perusahaan yang efeknya telah tercatat di Bursa Efek wajib memenuhi persyaratan-persyaratan yang berlaku dalam kedudukannya sebagai Perusahaan Tercatat. Pelanggaran terhadap ketentuann-ketentuan yang berlaku bagi perusahaan tercatat berakibat pada pengenaan sanksi baik oleh Bursa maupun OJK.

Penjatuhan sanksi delisiting bertujuan untuk: ${ }^{18}$

a. Untuk melindungi kepentingan publik dan dalam rangka penyelenggaraan perdagangan Efek yang teratur, wajar dan efisien, Bursa berwenanguntuk:

(1)Menghapus pencatatan Efek tertentu di Bursa;

(2) Menyetujui atau menolak permohonan pencatatan kembali termasuk penempatannya pada papan pencatatan dengan mempertimbangkan faktor-faktor yang menjadi penyebab delisting.

b. Dalam pengambilan keputusan yang terkait dengan Delisting dan Relisting, Bursa meminta Komite Pencatatan untuk memberikan pendapat.

c. Apabila saham Perusahaan Tercatat dilakukan Delisting, maka semua jenis Efek Perusahaan Tercatat tersebut juga dihapuskan dari daftar Efek yang tercatat di Bursa.

d. Dalam rangka pengambilan keputusan atas penghapusan pencatatan Efek, persetujuan atau penolakan atas permohonan pencatatan kembali Efek serta penempatannya pada Papan Utama atau

\footnotetext{
${ }^{18}$ Bursa Efek Indonesia, Peraturan No. I-I TentangPenghapusanPencatatan (delisting) dan PencatatanKembali (relisting) saham di bursa, Keputusan Direksi PT Bursa Efek Jakarta No. Kep308/BEJ/07-2004, Pasal II
}

Papan Pengembangan sebagaimana yang dimaksud dalam Peraturan ini, Bursa melakukan penelaahan atas keterangan-keterangan dan dokumen yang disampaikan Perusahaan Tercatat atau Calon Perusahaan.

Berdasarkan ketentuan III.3.1 Peraturan No. I-I Tentang Penghapusan Pencatatan dan Pencatatan Kembali, ${ }^{19}$ proses penjatuhan sanksi delisting diawali dengan rapat dengar pendapat antara Bursa dengan perusahaan tercatat. Dengar pendapat dilakukan dalam hal Bursa memerlukan penjelasan dalam rangka keterbukaan informasi Emiten atau pemenuhan kewajiban Emiten lainnya; Emiten mengajukan keberatan atas keputusan Penghentian Sementara Perdagangan Efek (Securities Halting); atau rencana Pembatalan Pencatatan Efek (Delisting) oleh Bursa atau Emiten bermaksud memberikan penjelasan dalam rangka keterbukaan informasi atau kejadian penting.

Dalam hal dengar pendapat dilakukan atas permintaan bursa, maka bursa akan menyampaikan secara tertulis kepada Emiten mengenai rencana pelaksanaan Dengar Pendapat, yang sekurang-kurangnya memuat tanggal, waktu, tempat serta alas annya. Apabila Emiten tidak hadir dalam Dengar Pendapat Pertama, maka Bursa menyampaikan secara tertulis rencana Dengar Pendapat kedua selambat-lambatnya 5 (lima) Hari Bursa setelah tanggal Dengar Pendapat pertama atau 1 (satu) Hari Bursa sejak Bursa menerima surat penundaan Dengar Pendapat dari Emiten. Apabila Emiten tidak hadir dalam Dengar Pendapat kedua, Bursa dapat langsung mengambil keputusan sesuai dengan ketentuan.

Selama berlangsungnya dengar pendapat, bursa berhak untuk merekam seluruh pembicaraan dalam dengar pendapat. Setelah dengar pendapat dilakukan, maka Bur-

\footnotetext{
${ }^{19}$ Bursa Efek Indonesia, Peraturan No. I-I TentangPenghapusanPencatatan (delisting) dan PencatatanKembali (relisting) saham di bursa, Keputusan Direksi PT Bursa Efek Jakarta No. Kep308/BEJ/07-2004, Pasal III
} 
sa dapat menetapkan keputusan berdasarkan Dengar Pendapat sebagai berikut: ${ }^{20}$

a. Mengenakan sanksi sebagaimana diatur dalam Peraturan Pencatatan Efek Nomor I.A.6 tentang Sanksi

b. Mencabut atau membatalkan sanksi yang telah dijatuhkan;

c. Mewajibkan Emiten untuk menyampaikan secara tertulis keterbukaan informasi atau hal lain yang dipandang perlu oleh Bursa;

d. Mewajibkan Emiten untuk melakukan Publik Ekspose

Dalamhal Bursa memutuskan untuk melakukan Delisting, maka Bursa membertahukan keputusan akan dilakukannya Delisting saham Perusahaan Tercatat termasuk jadwal pelaksanaannya kepada Perusahaan Tercatat yang bersangkutan pada Hari Bursa yang samadiputuskannya Delisting saham dimaksud dengan tembusan kepada $\mathrm{OJK}^{21}$

Bursa akan mengumumkan di Bursa mengenai keputusan Delisting saham Perusahaan Tercatat tersebut termasuk jadwal pelaksanaan Delisting saham Perusahaan Tercatat yang bersangkutan. Pengumuman dilakukan selambat lambatnya pada awal sesi I Hari Bursa berikutnya setelah diputuskannya Delisting saham dimaksud. Penghapusan saham secara paksa ini akan memberikan akibat yang juga tidak sedikit bagi pemegang saham, dan akhirnya juga berdampak buruk bagi manajemen perusahaan. ${ }^{22}$ Maka perusahaan tercatat tersebut tidak dapat lagi memperdagangkan sahamnya dilantai bursa dan saham tersebut tidak liquid. Secara Khusus, aturan Delisting secara perundang-undangan tidak diatur dalam perundangan Indonesia.

Forced delisting sejatinya merupakan suatu perlindungan hokum bagi investor pasar modal dariemiten yang mengalami keadaan atau peristiwa di bidang hokum maupun finansial yang mengganggu ke-

\footnotetext{
${ }^{20}$ Bursa Efek Indonesia, Peraturan Nomor

I.A.4 Tentang Dengar Pendapat Tahun 2002

${ }^{21}$ Hamud M Balfaz, Op.cit, hlm.307

${ }^{22}$ Ibid, hlm 309
}

langsungan perusahaannya, sehingga investtor terlepas dari kegiatan serta perusahaan yang melakukan kegiatan usaha dengan baik tetapi memiliki peminat saham yang sedikit. Delisting bukan bertujuan untuk mematikan perusahaan, tetapi untuk memberikan kesempatan bagi perusahaan tersebut untuk melakukan perbaikan, ${ }^{23}$ agar bias diadakan relisting, atau masuk kembali dari daftar kursresmi demi kebahagiaan dan keamanan pemegang saham. Karena hal ini sangat dekat dengan keterbukaan kinerja suatu perusahaan, banyak faktor yang mengakibatkan perusahaan tercatat terkena sanksi forced delising bukan hanya karena alasan mis management, bias saja kondisi perusahaan disebabkan bukan oleh sebabsebab perusahaan itu sendiri, tetapi bias saja karena factor lingkungan kerjanya yang mempengaruh. Suka runtuk mencari dana, ekonomi dunia krisis, ekonomi dalam negeri stagnant, daya beli masyarakat menurun, karena apabila membicrakan mengenai globalisasi ekonomi selalu memiliki siklus bisnis atau sering disebut dengan istilah business cycle. $^{24}$

2. Perlindungan hokum bagi investor yang mempunyai saham di emiten yang mengalam iforced delisting

Pada dasarnya Undang-Undang No. 8 Tahun 1995 tentang Pasar Modal sudah menjadi fondasi kuat bagi peraturan pelaksananya dalam melindungi dan memberikan jaminan kepastian untuk investor. Konsekuensi perlindungan bagi investor adalah diterapkannya prinsip full disclosure, karena setiap keputusan investasi mengandung risiko maka emiten dan profesi penunjang di pasar modal harus bertanggungjawab terhadap keakuratan data dan kelengkapan informasi. Masalah yang berkaitan dengan kepentingan investor harus diperhatikan oleh pemerintah, termasuk mengenai perbaikan manajemen perusahaan yang telah go public. Hal ini dirasa perlu untuk dilakukan dalam upaya untuk me-

23 E.A Koetin, Analisis Pasar Modal, (Jakarta: Pustaka Sinar Harapan, 1999), hlm 100

${ }^{24}$ Ibid, hlm. 100 
ningkatkan rasa percaya bagi investor untuk dapat menanamkan modal yang dimilikinya. Kepemilikan saham suatu perseroan oleh public menimbulkan konsekuensi bagi emiten untuk terus bertanggungjawab dalam setiap tindakannya serta aksi korporasi yang akan dijalan kannya membutuhkan peranan dari pemegang sahamnya. Namun dalam praktiknya pemegang saham minoritas seringkali berada dalam posisi yang lemah yang mengakibatkan terjadi monopoli yang dilakukan oleh pemegang saham mayoritas. ${ }^{25}$

Perlindungan pada pemegang saham minoritas perlu dilindungi karena pemegang saham sebagai pihak yang andilnya paling kecil dalam kegiatan usaha perseroan (tanpa mengesampingka nperanan pemegang saham dalam menentukan kebijakan-kebijakan major pengurusan perseroan),namun di lain sisi pemegang saham terekspos pada kemungkinan kerugian paling besar (berupa hilangnya modal yang ditanamkan dalam kekayaan perseroan itu sendiri). ${ }^{26}$ Dampak terhadap emiten pun demikian, atas diberlakukannya forced delisting mengakibatkan nilai investasi yang ditanamkan oleh investor pada perusahaan tersebut menjadi kehilangan nilai investasinya dikarenakan mendapatkan suspense oleh bursa sehingga jarang terjadi transaksi di pasar tunai dan pasar regular yang ada di Bursa yang dapat mengakibatkan nilai sahamnya menurun.

Perlindungan hokum bagi pemegang saham minoritas dapat dilakukan dalam gugatan derivative. Hal ini diatur secara jelas diatur dalam Pasal 61 Undang Undang Nomor 40 Tahun 2017 bertujuan untuk melindungi hak-hak dan kepentingan pemegang saham minoritas terhadap kesewenangwenangan pemegang saham mayoritas. $\mathrm{Pa}$ -

${ }^{25}$ AgusRiyanto, MENGAPA PEMEGANG SAHAM MINORITAS HARUS DILINDUNGI ? https://business-

law.binus.ac.id/2019/07/25/mengapa-pemegangsaham-minoritas-harus-dilindungi/\#, diakses pada 24 Mei 2020

${ }^{26}$ Chatamarrasjid., "PenerobosanCadar Perseroan Dan Soal-SoalAktualHukum Perusahaan, (PT Citra Aditya Bakti, Bandung, 2012)., hlm 228. sal ini membuka ruang gugatan dengan ketentuan bahwa setiap pemegang saham berhak mengajukan gugatan terhadap perseroan melalui Pengadilan Negeri, yang dasar hokumnya meliputi kedudukan perseroan yang merugikan kepentingannya dianggap tidak adil dan dilakukan tanpa alasan yang wajar sebagai akibat keputusan RUPS, Direksi dan/ atau dewan Komisaris.

Salah satu pilar untuk melindungi pihak pemegang saham minoritas dalam suatu Perseroan Terbatas dengan menghadirkan pihak pengadilan untuk melakukan intervensi kedalam Perseroan tersebut. Gugatan Derivatif (Derivative Action) adalah gugatan yang berdasarkan atas hakutama (primary right) dari Perseroan, tetapi dilaksanakan oleh pemegang saham atas nama Perseroan, gugatan mana dilakukan karena adanya suatu kegagalan dalam Perseroan atau dengan perkataan lain, derivative action merupakan suatu gugatan yang dilakukan oleh para pemegang saham untuk dan atas nama Perseroan.

Gugatan derivative adalah suatu gugatan berdasarkan hakutama (primary right) dariperseroan, tetapi dilaksanakan pemegang saham atas nama perseroan. Gugatan tersebut dilakukan karena adanya kegagalan dalam perseroan. Dengan perkataan lain, gugatan derivative merupakan suatu gugatan yang dilakukan oleh pemegang saham untuk dan atas nama perseroan. Dikatakan derivative karena gugatan tersebut diajukan oleh pemegang saham untuk dan atas nama perseroan, gugatan mana sebenarnya berasal dari (derived from) gugatan yang seharusnya dilakukan oleh perseroan. ${ }^{27}$

Dari pengertian gugatan derivative diatas, dapat ditarik ada beberapa unsur yang terkandung di dalam gugatan derivatif, yaitu: ${ }^{28}$

1. Adanya gugatan

2. Gugatan itu diajukan kepengadilan

${ }^{27}$ Ridwan Khairandy, Perseroan

TerbatasDoktrin, PeraturanPerundang-Undangan

dan Yurisprudensi, (Yogyakarta: Total Media, 2009) , hlm. 235

${ }^{28}$ Ibid., hlm 236 
3. Gugatan tersebut diajukan oleh pemegang saham perseroan yang bersangkutan

4. Pemegang saham mengajukan gugatan untuk dan atas nama perseroan

5. Pihak yang digugat selain pihak perseroan, biasanya direksi perseroan

6. Penyebab dilakukannya gugatan karena adanya kegagalan dalam perseroan atau kejadian yang merugikan perseroan yang bersangkutan

7. Karena diajukan untuk dan atas nama perseroan, maka segala hasil gugatan menjadi milik perseroan walaupun pihak yang mengajukan gugatan adalah pemegang saham.

Subyek yang mengajukan gugatan derivative adalah pihak pemegang saham, sedangkan gugatan tersebut ditujukan untuk kepentingan perseroan, maka pihak pemegang saham yang mengajukan gugatan derivative tersebut sering disebutkan dengan istilah guardian ad litem terhadap perusahaannya. Dalam hal ini, ketika ada gugatan derivative tersebut, yang menjadi penggugat atau tergugat umumnya bukan perseroan, meskipun ada system hukum yang mengharuskan perusahaan tetap sebagai pihak dalam gugatan tersebut, sehingga pihak perseroan akan menjadi pihak yang hanya bersikap pasif saja, dan baru bereaksi jika ada hal-hal yang merugikan perseroan. Dalam hal seperti ini, pihak perseroan disebut sebagai "tergugat nominal" (nominal defendant), dengan sedikit kesempatan membela diri, jika dalam berjalannya proses tersebut terdapat hal-hal yang dianggap dapat merugikan perseroan. ${ }^{29}$ Karena pemegang saham sebagai penggugat tidak mewakili dirinya sendiri, tetapi untuk perseroan dalam mengajukan gugatan, maka ada beberapa karakteristik khusus suatu gugatan derivatif, yaitu: ${ }^{30}$

1. Sebelum dilakukan gugatan sejauh mungkin dimintakan (demand) yang ber-

${ }^{29}$ Munir Fuady, HukumBisnisdalamTeori dan Praktek, (Bandung: PT. Citra Aditya Bakti,1996) hlm 260

${ }^{30}$ Ridwan Khairandy, Op.cit., hlm 237 wenang (direksi) untuk melakukan gugatan untuk dan atas nama perseroan sesuai ketentuan dalam anggaran dasarnya.

2. Pihak pemegang saham yang lain sejauh mungkin dimintakan juga partisi pasinya dalam gugatan derivatif, mengingat gugatan tersebut juga untuk kepentingannya.

3. Harus diperhatikan juga kepentingan stake holder yang lain, seperti pemegang saham yang lain, pihak pekerja, dan kreditor. Karena itu, bukan hanya pemegang saham penggugat yang harus didengar oleh pengadilan. Misalnya, dalam adanya penyelesaian di pengadilan, apabila penyelesaian tersebut cukup layak dan diterima oleh banyak pihak, pengadilan sepatutnya harus mengabulkan penyelesaian tersebut, meskipun pihak pemegang saham penggugat menolaknya

4. Tindakan penolakan gugatan derivative berdasarkan alasan ne bis in idem tidak boleh merugikan kepentingan pihak stake holder yang lain.

5. Harus dibatasi bahkan dilarang penerimaan manfaat oleh pemegang saham yang ikut terlibat dalam tindakan merugikan perseroan terhadap mana gugatan derivative diajukan, yakni manfaat dari ganti rugi yang diberikan terhadap gugatan derivative tersebut.

6. Seluruh manfaat yang diperoleh dari gugatan derivative menjadi milik perseroan.

7. Sebagai konsekuensinya, maka seluruh biaya yang diperlukan dalam gugatan derivative mesti ditanggung oleh pihak perseroan.

Gugatan derivative hanya diatur pada salah satu pasal yaitu pasal 97 ayat 6 (terhadap gugatan Direksi) dan pasal 114 ayat 6 (terhadap gugatan Komisaris) dari ketentuan tentang Direksi (Pasal 92-107) dan Komisaris (Pasal 108- 121) dalam UUPT 2007. Pokok yang diatur adalah hak pemegang saham dengan jumlah 1/10 untuk mengugat Direksi atau Komisa- 
ris, karena kesalahan atau kelalaian yang menimbulkan kerugian perseroan.

Dengan demikian, UUPT dapat digunakan sebagai landasan bagi investor yang merasa dirugikan oleh emiten dimana saham diinvestasikan. Sejauh ini, belum ada yang mewajibkan perusahaan harus membeli saham investor yang tidak setuju atas forced delisting yang dilakukan oleh bursa. Namun baru-baruini OJK mengeluarkan Rancangan Peraturan Otoritas Jasa Keuangan (RPOJK) 04/2020 tentang Penyelenggaraan Kegiatan Di Bidang Pasar Modal yang mewajibkan emiten yang dihapuskan pencatatan sahamnya secara paksa (forced delisting) oleh Bursa wajib membeli kembali seluruh saham yang beredar di publik. ${ }^{31}$ Dalam rancangan ini dijelaskan pada pasal 69 ayat $\mathrm{I}^{32}$ yang mewajibkan perusahaan tercatat yang penz. catatan efeknya dibatalkan oleh BEI melakukan pembelian kembali atas seluruh saham yang dimiliki oleh pemegang saham publik dan pemegang saham public kurang dari 50 pihak.

Hal ini tentu akan memberikan dampak naiknya kepercayaan masyarakat untuk terus berinvestasi pada pasar modal dimana akan memeberikan perlindungan berupa pembelian kembali atas saham (buyback) pada saat emiten sudah di foced delisting oleh Bursa.

\section{Kesimpulan}

1. Delisting bukan bertujuan untuk mematikan perusahaan, tetapi untuk memberikan ke-sempatan bagi perusahaan tersebut untuk melakukan perbaikan agar bisa diadakan relisting, atau masuk kembali dari daftar kurs resmi demi kebahagiaan dan keamanan pemegang saham.

\footnotetext{
${ }^{31}$ SyahrizalSidik, Emiten Delisting

WajibBuybackSahamPublik,

https://www.cnbcindonesia.com/market/2020021718 0913-17-138516/emiten-delisting-wajib-buybacksaham-publik, diakses pada tanggal 25 Mei 2020

${ }^{32}$ OtoritasJasaKeuangan,

RancanganPeraturanOtoritasJasaKeuangan No. 04 Tahun 2020 TentangPenyelenggaraanKegiatan Di Bidang Pasar Modal.
}

Hakikatnya forced delis-ting memberikan suatu perlindungan hukum bagi investor pasar modal dariemiten yang mengalami keadaan atau peristiwa di bi-dang hukum maupun finansial yang meng-ganggu kelangsungan perusahaannya, se-hingga investor terlepas dari kegiatan serta perusahaan yang melakukan kegiatan usaha dengan baik tetapi memiliki peminat saham yang sedikit. Pertimbangan Bursa Efef Indonesia dalam melakukan forced delisting terhadap emiten yang tidak sehat didasarkan pada perusahaan yang mengalami kondisi, atau peristiwa yang secara signifikan berpengaruh negatif terhadapkelangsungan usaha perusahaan tercatat di Bursa Efek Indonesia, baik secara finansial atau secara hukum, atau terhadap kelangsungan status emiten.

Perlindungan hukum yang dapat dilakukan oleh investor apabila perusahaan mengalami forced delisting adalah melakukan gugatan derivatif sebagaimana diatur dalam Undang Undang Nomor 40 Tahun 2007 tentang Perseroan Terbatas. Kendati demikian, dengan adanya usulan dalam rangka melindungi investor, melalui Rancangan Peraturan Otoritas Jasa Keuangan No. 04 Tahun 2020 Tentang Penyelenggaraan Kegiatan Di Bidang Pasar Modal akan diberlakukan kewajiban untuk emiten yang terkena forced delisting untuk membeli kembali saham yang sudah diterbitkannya (buyback). Diharapkan agar rancangan ini dapat diberlakukan agar menumbuhkan rasa kepercayaan terhadap investor. 


\section{DAFTAR PUSTAKA}

\section{Buku}

Chatamarrasjid., "PenerobosanCadar Perseroan Dan Soal-SoalAktualHukum Perusahaan, (PT Citra Aditya Bakti, Bandung, 2012)

E.A Koetin, Analisis Pasar Modal, (Jakarta: PustakaSinarHarapan, 1999)

Hamud M. Balfas, Hukum Pasar Modal Indonesia, (Jakarta: PT. Tata Nusa, 2012)

Kansil, C.S.T., Pokok-PokokHukum Pasar Modal, (Jakarta: Pustaka Sinar Harapan, 2004)

M.IrsanNasarudin, et al., Aspek Hukum Pasar Modal Indonesia, (Jakarta : KencanaPrenada Media Group, 2010)

Munir Fuady, Hukum Bisnis dalamTeori dan Praktek, PT. Citra Aditya Bakti, Bandung, 1996

Ridwan Khairandy, Hukum Pasar Modal 1, (Yogyakarta: FH UII Press, 2010)

Ridwan Khairandy, Perseroan Terbatas Doktrin, Peraturan Perundang-Undangan dan Yurisprudensi, (Yogyakarta: Total Media, 2009)

\section{Website}

AgusRiyanto, MENGAPA PEMEGANG SAHAM MINORITAS HARUS DILINDUNGI ?, https://business-law.binus.ac.id/2019/07/25/mengapa-pemegang-saham-minoritasharus-dilindungi/\#, diakses pada 24 Mei 2020

Annisaayuartanti, BEI CatatJumlah Investor Pasar Modal Meningkat 53\%, https://www.medcom.id/ekonomi/bursa/ybJVw5ab-2019-bei-catat-jumlah-investorpasar-modal-meningkat-53diakses pada tanggal 4 april 2020

Annisa Saumi, "OJK: Pasar modal Indonesia tumbuhpesatdari negara lain", https://www.alinea.id/bisnis/ojk-pasar-modal-indonesia-tumbuh-pesat-dari-negaralain-b1Xoz9o4h, diakses pada tanggal 20 Mei 2020

Investor Daily, "MenjagaKepercayaan Pasar"https://investor.id/editorial/menjagakepercayaan-pasar, diakses pada tanggal 1 april 2020

SyahrizalSidik, Emiten Delisting WajibBuybackSahamPublik, https://www.cnbcindonesia.com/market/20200217180913-17-138516/emitendelisting-wajib-buyback-saham-publik, diakses pada tanggal 25 Mei 2020

Wahyu Tri Rahmawati, BEI akan delisting saham Leo Investments (ITTG) Kamis (23/1) besok, https://investasi.kontan.co.id/news/bei-akan-delisting-saham-leo-investmentsittg-kamis-231-

besok\#: :text=BEI\%20delisting\%20paksa\%20Leo\%20Investments,lebih\%20dari\%2 0dua\%20tahun\%20disuspensi.\&text=BEI\%20mengumumkan\%20potensi\%20delistin g\%20ITTG,saham\%20emiten\%20pada\%2019\%20Desember., diakses pada tanggal 22 Mei 2020

Wahyu Tri Rahmawati, Saham Borneo Lumbung Energi\& Metal (BORN) delisting hariini, https://investasi.kontan.co.id/news/saham-borneo-lumbung-energi-metal-borndelisting-hari-ini, diakses pada tanggal 22 Mei 2020

SyahrizalSidik, Emiten Delisting WajibBuybackSahamPublik, https://www.cnbcindonesia.com/market/20200217180913-17-138516/emitendelisting-wajib-buyback-saham-publik, diakses pada tanggal 25 Mei 2020

\section{PeraturanPerundang-Undangan}

Bursa Efek Indonesia, PerubahanPeraturanNomor I-A tentangPencatatanSaham dan EfekBersifatEkuitasSelainSaham yang Diterbitkan Oleh Perusahaan Tercatat, Keputusan Direksi PT. Bursa Efek Indonesia No. Kep-OOI83/BE1112-2018. 
Bursa Efek Indonesia, PeraturanNomor I.A.4 TentangDengarPendapatTahun 2002

Bursa Efek Indonesia, Peraturan No. I-I TentangPenghapusanPencatatan (delisting) dan PencatatanKembali (relisting) saham di bursa, Keputusan Direksi PT Bursa Efek Jakarta No. Kep308/BEJ/07-2004.

OtoritasJasaKeuangan, RancanganPeraturanOtoritasJasaKeuangan No. 04 Tahun 2020 TentangPenyelenggaraanKegiatan Di Bidang Pasar Modal.

RepublikIndonesia, Undang-UndangTentang Pasar Modal No.8 Tahun 1995.

Republik Indonesia, Undang-UndangTentang Perseroan Terbatas No.40 Tahun 2007 
Lex Librum : Jurnal Ilmu Hukum, Vol. 7 No.2, Juni 2021, hal. 99-110 